\begin{tabular}{l|l|l} 
Jurnal Eksplorasi Akuntansi & $\begin{array}{l}\text { ISSN : 2656-3649 (Online) } \\
\text { Vol. 1, No 3, Seri B, Agustus 2019, Hal 1013-1032 }\end{array}$
\end{tabular}

\title{
PENGARUH SIKLUS HIDUP PERUSAHAAN DALAM MEMODERASI HUBUNGAN MANAJEMEN LABA DAN COST OF EQUITY CAPITAL
} (Studi Empiris Pada Perusahaan Manufaktur Yang Terdaftar Di Bursa Efek Indonesia Tahun 2013-2017)

\author{
Indri Adelina Rizal ${ }^{1}$, Nurzi Sebrina ${ }^{2}$ \\ 1)Alumni Jurusan Akuntansi Fakultas Ekonomi, Universitas Negeri Padang \\ 2)Jurusan Akuntansi Fakultas Ekonomi Universitas Negeri Padang \\ *Korespondensi: indriadellinariza1090997@ gmail.com
}

\begin{abstract}
This study aims to provide empirical evidence whether earnings management can influence the cost of equity capital and whether the company's life cycle can strengthen or weaken the relationship between earnings management and the cost of equity capital. Profit Management in this study was measured using a discretionary accrual proxy. The company's life cycle is measured using the company's cash flow pattern and the cost of equity capital measured using measurements from Ohlson's (1995) model modified by Utami (2005). This study is classified as causative research. The population in this study are manufacturing companies listed on the Indonesian Stock Exchange period of 2013 to 2017.By using purposive sampling method, there were 60 companies as the research's sample. The type of data used is secondary data obtained from www.idx.co.id. The analysis used in this study is multiple linear regression analysis. The results of this study are that earnings management has no significant positive effect on the cost of equity capital and the company's life cycle is not able to strengthen or weaken the relationship of earnings management with the cost of equity capital.
\end{abstract}

Keywords : Earnings Management; Company's Life Cycle; and Cost of Equity Capital.

How to cite (APA $6^{\text {th }}$ style)

Rizal, I.A., \& Sabrina, N. (2019). Pengaruh Siklus Hidup Perusahaan dalam Memoderasi Hubungan Manajemen Laba dan Cost of Equity Capital (Studi Empiris pada Perusahaan Manufaktur yang Terdaftar di Bursa Efek Indonesia Tahun 2013-2017). Jurnal Eksplorasi Akuntansi, 1(3), Seri B, 1013-1032.

\section{PENDAHULUAN}

Perekonomian di Indonesia sudah berkembang dengan sangat pesat dan maju. Bukti yang menunjukkan bahwa perekonomian di Indonesia sudah maju adalah dengan banyaknya investor yang menanamkan modalnya pada perusahaan-perusahaan yang terdapat di Indonesia, terutama pada perusahaan go public yang terdaftar di Bursa Efek Indonesia. Perusahaan harus menyajikan laporan keuangan yang transparan dan akurat.Investor harus melihat kinerja keuangan yang ada 
di perusahaan, guna menjadi pedoman oleh investor dalam mengambil keputusan untuk berinvestasi pada perusahaan.

Laporan keuangan merupakan alat komunikasi manajer perusahaan dengan stakeholder. Husnanet al. (1996) dan Hanafi (1997) menyatakan bahwa laporan keuangan memiliki kandungan informasi. Perusahaan yang menyajikan laporan keuangan yang tidak transparan dan tidak menunjukkan keadaan perusahaan yang sebenarnya, akan menyebabkan terjadinya asimetri informasi yang akan menciptakan risiko informasi pada perusahaan. Risiko informasi yang diciptakan karena perusahaan menyajikan laporan keuangan yang bias, dapat menciptakan risiko investasi.

Investor yang menanamkan modalnya pada perusahaan yang menyajikan laporan keuangan yang bias, akan berpeluang memiliki risiko investasi sebesar modal yang ditanamkannya, karena risiko informasi akan memberikan peluang kepada investor untuk mengalami kerugian. Informasi yang diungkapkan oleh perusahaan akan membantu investor dan kreditur dalam memahami risiko investasi yang akan dihadapi. Untuk mengurangi risiko informasi, perusahaan harus menyajikan informasi yang akurat dan menunjukkan keadaan yang sebenarnya. Semakin kecil ketimpangan informasi yang terjadi antara manager dan pemegang saham, maka semakin kecil juga biaya yang ditanggung perusahaan (Ifonie, 2012). Risiko investasi atas saham perusahaan berkaitan dengan biaya modal ekuitas (cost of equity capital).

Cost of equity capital dapat dikatakan sebagai biaya yang dikeluarkan perusahaan untuk memenuhi kewajiban perusahaan tersebut, yaitu memenuhi hak para investor yang berupa return atas investasi yang telah ditanamkannya. Biaya modal ekuitas adalah pengembalian yang diperlukan pemegang saham atas investasi mereka di perusahaan dan secara luas digunakan dalam penilaian proyek investasi dan estimasi risiko ekuitas premi (Camaraet al., 2009).

Menurut Healy dan Palepu (1993) penyebab ketidak sempurnaan dan tidak transparannya komunikasi melalui laporan keuangan ada tiga kondisi yaitu: yang pertama, dibandingkan dengan investor, manajemen memiliki informasi yang lebih banyak tentang strategi dan operasi bisnis yang dikelolanya. Kedua, kepentingan manajer tidak selalu sejalan dengan kepentingan investor. Ketiga, ketidak sempurnaan dari aturan akuntansi dan audit. Tindakan yang biasanya dilakukan pihak manajemen dalam mempengaruhi angka pada laporan keuangan adalah manajemen laba. Stolowy dan Breton (2000) menjelaskan bahwa manipulasi akun dalam laporan keuangan dilakukan semata-mata didasarkan pada keinginan manajemen untuk mempengaruhi persepsi investor atas risiko perusahaan.

Manajemen laba menyebabkan banyak informasi bias dan tidak akurat yang diungkap oleh perusahaan, sehingga berpengaruh terhadap biaya modal ekuitas yang akan ditanamkan oleh investor. Biaya modal ekuitas (cost of equity capital) meningkat seiring dengan meningkatnya manajemen laba yang dilakukan perusahaan (Utami, 2005). Manajemen laba yang dilakukan oleh manajemen menyebabkan risiko informasi perusahaan meningkat. Informasi kompetitif yang sempurna akan mempengaruhi biaya modal ekuitas perusahaan dan perusahaan juga dapat mengurangi biaya modal dengan pengungkapan yang lebih baik (Lambert et al, 2012).

Hughes et al (2007) menyatakan bahwa tingkat informasi total dari pasar menggambarkan bahwa informasi yang besar asimetri atau ketimpangan informasi yang lebih besar, menyebabkan biaya modal ekuitas (cost of equity capital) menjadi lebih tinggi. Verrechia (1991) menjelaskan bahwa dengan mengungkapkan informasi yang akurat dapat menyebabkan tuntutan investor terhadap kompensasi menurun karena biaya transaksi turun sehingga komponen asimetri informasi berkurang, dan akhirnya cost of equity capitaljuga akan turun. 
Penelitian mengenai pengaruh manajemen laba terhadap cost of equity capital telah dilakukan oleh peneliti-peneliti sebelumnya baik nasional maupun internasional. Penelitian Ifonie (2012) telah meneliti pengaruh asimetri informasi dan manajemen laba terhadap cost of equity capital pada perusahaan real estate yang terdaftar di Bursa Efek Indonesia. Hasil penelitian menyatakan bahwa asimetri informasi dan manajemen laba berpengaruh positif namun tidak signifikan terhadap cost of equity capital. Penelitian yang dilakukan oleh Jumirin (2011), Utami (2005) dan Caecilia dan Sigit (2012) yang menunjukkan bahwa manajemen laba mempunyai pengaruh positif secara signifikan terhadap biaya modal ekuitas.

Hasil penelitian terdahulu yang masih belum konsisten dapat disebabkan karena penelitian terdahulu mengabaikan variabel siklus hidup perusahaan. Hasan et al (2015) menyatakan bahwa siklus hidup perusahaan memiliki implikasi penting untuk menarik investor, yang pada akhirnya meningkatkan likuiditas saham dan mempengaruhi biaya modal ekuitas (cost of equity capital). Siklus hidup perusahaan merupakan perkembangan perusahaan yang ditandai dengan adanya tahapan-tahapan yang dilalui oleh setiap perusahaan.

Perusahaan yang berada pada setiap siklus hidup perusahaan memiliki aliran kas, struktur pengendalian internal,dan sumber daya profesional yang berbeda. Perusahaan yang berada pada tahap pengenalan dan pertumbuhan, membutuhkan dana yang lebih besar dari pihak eksternal karena belum mampu untuk mendanai perusahaan, sehingga perusahaan harus menyajikan laporan keuangan yang menunjukkan bahwa perusahaan memiliki kinerja yang bagus guna untuk menarik investor. Kondisi tersebut memotivasi perusahaan untuk melakukan praktik manajemen laba, seperti memanipulasi akun-akun yang pada laporan keuangan.

Pada tahap ini perusahaan melakukan manajemen laba lebih besar dibandingkan dengan perusahaan yang berada pada tahap mature dan decline. Pada tahap mature dan decline perusahaan memiliki struktur pengendalian internal yang canggih dan ketat, sehingga kesempatan perusahaan untuk melakukan manajemen laba kecil. Hasan et al (2015) menyatakan bahwa siklus hidup memiliki pengaruh yang signifikan pada kemampuan perusahaan untuk menarik investor, yang akhirnya mempengaruhi biaya modal ekuitas perusahaan ex-ante. Hal tersebut membuat peneliti tertarik menjadikan siklus hidup perusahaan menjadi variable moderasi.

Penelitian tentang faktor yang mempengaruhi cost of equity capital sudah banyak di lakukan di Indonesia, akan tetapi penelitian yang umumnya dibahas cenderung terkait dengan pengaruh ukuran perusahaan, leverage, risiko sistematis, atau nilai pasar, sedangkan penelitian yang terkait dengan hubungan antara manajemen laba dengan cost of equity capital yang dimoderasi oleh siklus hidup perusahaan masih sangat terbatas. Oleh karena itu, penulis tertarik untuk mengangkat masalah ini dalam suatu penelitian yang bertujuan untuk memperoleh bukti empiris apakah manajemen laba dapat mempengaruhi cost of equity capital dan apakah siklus hidup perusahaan dapat memperkuat atau memperlemah hubungan antara manajemen laba dengan cost of equity capital.

Peneliti tertarik untuk meneliti pada perusahaan manufaktur yang terdaftar di BEI, karena perusahaan manufaktu rmerupakan perusahaan yang kegiatannya mengolah bahan baku menjadi barang jadi. Selain itu alasan peneliti menggunakan perusahaan manufaktur yang terdaftar di BEI sebagai sampel, karena perusahaan-perusahaan yang listing di BEI banyak berasal dari perusahaan manufaktur. Penelitianini bertujuan untuk memberikan bukti empiris mengenai pengaruh siklus hidup perusahaan dalam memoderasi hubungan manajemen laba dan cost of equity capital, pada perusahaan manufaktur yang terdaftar di Bursa Efek Indonesia tahun 20132017. 


\section{REVIU LITERATUR DAN PENGEMBANGAN HIPOTESIS}

\section{Teori Asimetri Informasi}

Adanya pemisahan fungsi dan perbedaan kepentingan pada perusahaan dapat menyebabkan permasalahan seperti asimetri informasi antara pihak internal dengan pihak eksternal perusahaan. Komalasari (2001) menyatakan bahwa mengimplikasikan adanya asimetri informasi antara manajer sebagai agen dan pemilik sebagai prinsipal. Menurut Jensen dan Meckling (1976) asimetri informasi merupakan suatu keadaan dimana manajer memiliki akses informasi atas prospek perusahaan yang tidak dimiliki oleh pihak luar perusahaan. Kondisi tersebut memberikan manajemen kesempatan untuk melakukan manajemen laba.

Asimetri informasi akan mendorong manajer untuk menyajikan informasi yang tidak sebenarnya terutama jika informasi yang disajikan tersebut berkaitan dengan pengukuran kinerja manajemen. Supriyono (2000) menyatakan bahwa asimetri informasi merupakan situasi yang terbentuk akibat prinsipal tidak memiliki informasi yang cukup mengenai kinerja agen sehingga prinsipal tidak pernah dapat menentukan kontribusi usaha-usaha agen terhadap hasil perusahaan yang sesungguhnya.

\section{Teori Keagenan}

Anthony dan Govindarajan (2005) mengatakan bahwa teori agensi merupakan hubungan kontrak antara principal dan agen. Teori keagenan mendeskripsikan hubungan antara pemegang saham (shareholders) sebagai prinsipal dan manajemen sebagai agen yang menjalankan perusahaan maka akan muncul permasalahan agensi karena masing-masing pihak tersebut akan selalu berusaha untuk memaksimalkan fungsi utilitasnya. Manajemen adalah pihak yang dikontrak oleh pemegang saham untuk bekerja demi kepentingan dan mensejahterakan pemegang saham. Karena mereka dipilih, maka pihak manejemen harus mempertanggungjawabkan semua pekerjaannya kepada pemegang saham dengan memaksimalkan nilai perusahaan.

Agency theory dapat menimbulkan masalah mendasar dalam organisasi yaitu perilaku untuk mementingkan diri sendiri. Dengan asumsi bahwa individu-individu bertindak untuk memaksimalkan kepentingan diri sendiri, maka dengan asimetri informasi yang dimilikinya akan mendorong agen untuk menyembunyikan beberapa informasi yang tidak diketahui prinsipal. Dalam kondisi yang asimetri tersebut, agen dapat mempengaruhi angka-angka akuntansi yang disajikan dalam laporan keuangan dengan cara melakukan manajemen laba. Terpisahnya fungsi antara pemilik dengan manajemen memiliki dampak keleluasaan manajemen dalam memaksimalkan laba, hal ini mengarah pada proses memaksimalkan kepentingan manajemen sendiri dengan biaya yang harus ditanggung oleh pemilik perusahaan (Ismunandar, 2009).

\section{Manajemen Laba}

Manajemen laba merupakan upaya manajer untuk mengintervensi informasi dalam laporan keuangan dengan tujuan untuk mengelabui stakeholders yang ingin mengetahui kinerja dan kondisi perusahaan (Sulistyanto, 2008 : 6). Healy dan Wahlen (1999) menyatakan bahwa manajemen laba terjadi ketika manajer menggunakan pertimbangan di (dalam) pelaporan keuangan dan di (dalam) transaksiyang terstruktur untuk mengubah laporan keuangan yang dapat menyesatkan beberapa stakeholders tentang dasar kinerja ekonomi perusahaan atau untuk mempengaruhi hasil sesuai kontrak yang tergantung pada angka-angka akuntansi dilaporkan.

Manajemen laba yang dilakukan oleh manajemen bertujuan untuk menghasilkan laporan keuangan yang menggambarkan kondisi perusahaan yang baik karena laba yang terdapat didalam laporan keuangan terlihat bagus dan stabil, akibatnya nilai perusahaan menjadi 
meningkat sehingga dapat menarik minat investor untuk menanamkan modal di perusahaan tersebut.

\section{Siklus Hidup Perusahaan}

Teori siklus hidup perusahaan berasal dari literatur ilmu organisasi. Penrose (1959) memberikan teori umum tentang pertumbuhan perusahaan dan berpendapat bahwa pertumbuhan perusahaan tergantung pada sumber daya dan peluang produktif mereka. Siklus hidup perusahaan merupakan perkembangan perusahaan yang ditandai dengan adanya tahapan-tahapan yang dilalui oleh setiap perusahaan. Siklus hidup perusahaan dimulai dari tahap pendirian menuju tahap pendewasaan, hingga perusahaan berada di tahap dimana perusahaan mengalami penurunan.

Menurut Damodaran (2011: 511) model siklus hidup perusahaan dapat terbagi kedalam empat tahapan diantaranya tahap pengenalan, tahap pertumbuhan, tahap kematangan atau tahap pendewasaan dan tahap penurunan. Fama dan French (2001) membagi tahapan daur hidup menjadi dua yakni strong growth (tahapan growth) dan lowgrowth (tahapan mature).

Setiap perusahaan memiliki tahapan dalam perkembangan atau evolusi, sama halnya dengan siklus hidup produk (Schori dan Garee: 1998). Pada saat start-up perusahaan digambarkan seperti anak kecil yang baru belajar berjalan.Pada tahapan growth, perusahaan digambarkan seperti anak remaja yang belum dewasa. Pada tahap mature, perusahaan digambarkan seperti orang dewasa. Tahapan terakhir dari siklus hidup perusahaan adalah tahap decline. Pada tahap ini perusahaan digambarkan sebagai orang yang lanjut usia.

\section{Cost of Equity Capital}

Menurut Riyanti (1996), biaya modal ekuitas merupakan bagian yang harus dikeluarkan oleh perusahaan untuk memberi kepuasan kepada investornya pada tingkat risiko tertentu. Biaya modal ekuitas merupakan tingkat hasil minimum yang harus dicapai oleh perusahaan atas dana yang telah diinvestasikan dalam suatu proyek yang bersumber dari modal sendiri agar saham perusahaan di pasar saham tidak mengalami perubahan. Biaya modal ekuitas berkaitan dengan risiko investasi. Efek yang lebih beresiko harus memiliki tingkat pengembalian yang diharapkan lebih tinggi seperti yang diestimasikan oleh investor dengan margin pengembalian efek kurang beresiko di dalam pasar yang di dominasi oleh investor yang menghindari risiko. Semakin tinggi tingkat risiko atau efek, pengembalian yang diharapkan juga harus makin tinggi untuk menarik investor agar membeli (memiliki) efek tersebut.

Biaya modal ekuitas merupakan tingkat pengembalian yang diharapkan investor terhadap investasi yang telah ditanamkannya pada perusahaan. Konsep biaya modal ini dimaksudkan untuk dapat menentukan besarnya biaya riil yang harus ditanggung oleh perusahaan untuk memperoleh dana dari sumber atau penggunaan modal dari masing-masing sumber dana, untuk kemudian menentukan biaya modal rata-rata (average cost of capital) dari keseluruhan dana yang digunakan oleh perusahaan tersebut.

\section{Penelitian Terdahulu}

Penelitian terdahulu yang meneliti hubungan manajemen laba dengan cost of equity capital adalah penelitian yang dilakukan olehWiwik Utami (2005), Ali Imran (2011), Ifonie (2012), Achmad dkk (2014) dan Nia (2015). dan Dengan ringkasan hasil sebagai berikut:

a. Manajemen Laba berpengaruh positif signifikan terhadap cost of equity capital. (Utami, 2005; Ali Imran, 2011; Achmad dkk, 2014; Nia, 2015) 
b. Manajemen Laba berpengaruh positif tidak signifikan terhadap cost of equity capital (Ifonie, 2012; Agus dkk, 2014).

c. Siklus hidup perusahaan berpengaruh terhadap cost of equity capital sehingga menyerupai pola berbentuk-U. (Hasanet al., 2015).

\section{Manajemen Laba dan Cost of Equity Capital}

Manajemen laba akan meningkatkan risiko perusahaan jika tindakan tersebut dilakukan bertujuan untuk menutupi kinerja perusahaan yang tidak baik. Manajemen laba dilakukan semata-mata untuk mempengaruhi persepsi investor atas risiko perusahaan (Stowoly dan Breton, 2000). Risiko tersebut dapat dibagi kedalam dua komponen, yaitu risiko yang dihubungkan dengan variasi imbal hasil yang diukur dengan laba per lembar saham (earning per share) dan risiko yang dihubungkan dengan struktur keuangan perusahaan yang diukur dengan debt equity ratio, sehingga tujuan manajemen adalah untuk memperbaiki ukuran kedua risiko tersebut. Semakin tinggi tingkat manajemen laba menunjukkan semakin tinggi risiko imbal hasil saham dan konsekuensinya investor akan menaikkan rate biaya modal ekuitas.

Dechow et al. (1996) menyatakan bahwa tindakan manajer melakukan manajemen laba merupakan sinyal yang buruk dimasa depan, karena pasar bereaksi secara negatif yang artinya manajemen laba ditanggapi buruk oleh pelaku pasar sehingga menurunkan likuiditas dan harga saham yang akan berdampak terhadap meningkatnya cost of equity capital. Manajemen laba yang dilakukan oleh manajemen meyebabkan informasi yang disajikan oleh perusahaan untuk stakeholder-nya menjadi tidak akurat dan terciptanya ketimpangan informasi sehingga risiko informasi meningkat. Risiko informasi yang tinggi menunjukkan informasi yang disajikan perusahaan bersifat bias dan tidak mencerminkan keadaan perusahaan yang sebenarnya, sehingga risiko investasi juga akan meningkat.

Hasil penelitian Francis et al. (2004, 2005) dan Utami (2005) menunjukkan bahwa manajemen laba mempunyai pengaruh positif terhadap biaya modal ekuitas. Semakin besar praktik manajemen laba yang dilakukan oleh perusahaan maka semakin besar biaya yang harus dikeluarkan oleh perusahaan.Namun berdasarkan penelitian Purwaningtias dan Surifah (2015), Purwanto (2013) dan Andriani (2013) menunjukkan bahwa manajemen laba tidak berpengaruh signifikan terhadap biaya modal ekuitas.

$\mathbf{H}_{1}$ : Manajemen laba mempunyai pengaruh positif terhadap cost of equity capital

\section{Manajemen Laba, Siklus Hidup Perusahaan dan Cost of Equity Capital}

Scott (2000) menyatakan bahwa pada tahap start-up, manajemen melakukan pengenalan kepada pihak eksternal (publik). Aliran arus kas yang dimiliki perusahaan pada tahap ini cenderung masih rendah sehingga perusahaan melakukan praktik manajemen laba. Faktor lain yang menjadi faktor bagi perusahaan untuk melakukan praktik manajemen laba adalah struktur pengendalian yang relatif rendah. Struktur pengendalian yang rendah dikarenakan pada tahap ini perusahaan belum memiliki sumber daya yang profesional dan belum ahli.

Perusahaan yang berada pada tahap pertumbuhan mempunyai sistem pengendalian yang relatif rendah dan lemah, sehingga kesempatan manajemen untuk melakukan praktik manajemen laba semakin besar. Praktik manajemen laba yang dilakukan oleh manajemen pada tahap ini disebabkan karena perusahaan masih berada pada tahap harus meningkatkan pertumbuhan penjualan dan mempertahankan nilai pasar sahamnya. Perusahaan cenderung melakukan manajemen laba lebih tinggi dengan menaikkan laba pada tahun berjalan agar menunjukkan 
bahwa kinerja perusahaan semakin meningkat karena pada tahap ini kondisi keuangan perusahaan cenderung masih belum stabil (Hastuti, 2011).

Perusahaan yang berada pada tahap dewasa memiliki umur atau keberadaan yang lebih lama di pasar sehingga diikuti oleh analis dan investor, serta di ketahui oleh masyarakat. Perusahaan tahap dewasa mempunyai lebih sedikit ketimpangan informasi dan kurang berisiko. Studi sebelumnya (Gebhardt et al. 2001) menunjukkan bahwa kematangan perusahaan terkait dengan penurunan risiko sistematis. Perusahaan yang berada pada tahap dewasa memiliki sistem pengendalian yang relatif ketat dan canggih dibandingkan dengan tahap pertumbuhan, sehingga kesempatan manajemen untuk melakukan manajemen laba jadi lebih rendah dibandingkan dengan tahap pertumbuhan.

Menurut Hastuti (2011) bahwa pada tahap decline kondisi keuangan perusahaan lebih stabil, tidak mengalami peningkatan penjualan yang signifikan namun penurunan laba yang cukup drastis, sehingga praktik manajemen laba yang dilakukan manajer cenderung kecil atau perusahaan tidak perlu melakukan manajemen laba. Tingkat pertumbuhan penjualan rendah, laba yang dihasilkan perusahaan tidak lagi banyak ditahan untuk pengembangan perusahaan, dan perusahaan tidak melakukan pengeluaran modal besar-besaran. Hastuti (2011) menyatakan bahwa perusahaan pada tahap ini melakukan praktik manajemen laba yang relatif kecil dibandingkan dengan perusahaan yang berada pada tahap dewasa (mature), karena pada tahap decline perusahaan telah memiliki pengendalian internal yang canggih dan relatif lebih ketat serta auditor internal yang kompeten dibandingkan dengan tahap mature.

H2: Semakin rendah praktik manajemen laba maka cost of equity capital juga akan rendah, hubungan tersebut menguat atau melemah pada saat tahapan siklus hidup perusahaan semakin tinggi

\section{Kerangka Konseptual}

Berdasarkan pengembangan hipotesis, maka kerangka konseptual penelitian ini dapat dilihat pada Gambar 1. Pada penelitian ini juga digunakan variabel kontrol yaitu, ukuran perusahaan (firm size) dan leverage pada tiap-tiap hipotesis penelitian.

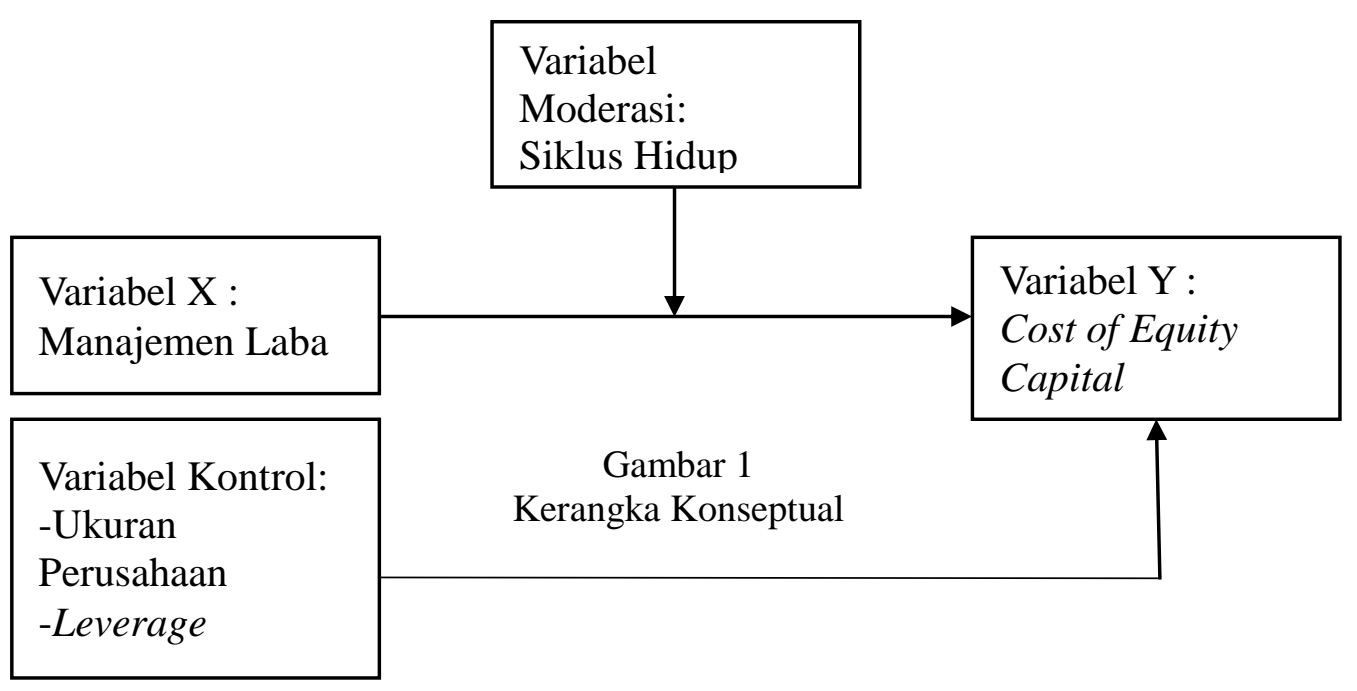




\section{METODE PENELITIAN}

Jenis penelitian ini termasuk kedalam penelitian eksplanatoris kausatif. Jenis data adalah data sekunder. Data yang diperlukan dalam penelitian ini berupa laporan keuangan perusahaan manufaktur yang dipublikasikan tahun 2013-2017. Sumber data berasal dari situs resmi Bursa Efek Indonesia yaitu www.idx.co.id. Data ini berbentuk time series dan cross section sehingga data yang digunakan adalah data panel.

Populasi yang akan diamati dalam penelitian ini adalah seluruh perusahaan manufaktur yang terdaftar di Bursa Efek Indonesia (BEI) selama periode pengamatan yaitu tahun 2013-2017. Teknik pengambilan sampel yang digunakan dalam penelitian ini adalah purposive sampling. Kriteria yang digunakan dalam pemilihan sampel adalah perusahaan manufaktur yang terdaftar di Bursa Efek Indonesia, memiliki data lengkap terkait variabel yang digunakan dalam penelitian, dan menyajikan mata uang rupiah ( $\mathrm{Rp}$ ) yang konsisten selama periode pengamatan, yaitu tahun 2013-2017. Sehingga didapatkan sampel untuk penelitian sebanyak 60 perusahaan.

Tabel 1

Kriteria Penentuan Sampel

\begin{tabular}{|c|l|c|}
\hline No. & \multicolumn{1}{|c|}{ Keterangan } & Jumlah Perusahaan \\
\hline 1. & $\begin{array}{l}\text { Perusahaan manufaktur yang terdaftar di BEI } \\
\text { periode tahun 2013-2017 }\end{array}$ & 159 \\
\hline 2. & $\begin{array}{l}\text { Perusahaan manufaktur yang tidak lengkap } \\
\text { laporan keuangan di BEI periode tahun 2013-2017 }\end{array}$ \\
\hline 3. & $\begin{array}{l}\text { Perusahaan manufkatur yang tidak memiliki data } \\
\text { lengkap terkait variabel-variabel penelitian }\end{array}$ & $(32)$ \\
\hline 4. & $\begin{array}{l}\text { Perusahaan manufaktur yang menyajikan laporan } \\
\text { keuangan tidak dalam rupiah periode 2013-2017 }\end{array}$ \\
\hline \multicolumn{2}{|c|}{ Total sampel yang digunakan dalam penelitian } & $\mathbf{6 0}$ \\
\hline
\end{tabular}

(Sumber: IDX.co.id, data diolah)

\section{Variabel Penelitian \& Pengukurannya \\ Cost of Equity Capital}

Variabel dependen dalam penelitian ini adalah cost of equity capital. Mengikuti penelitian oleh Ohlson (1995), Botosom (1997) dan Utami (2005), cost of equity capital diukur dengan menggunakan model Ohlson, yaitu:

$$
r=\frac{\left(B_{t}+X_{t+1}-P_{t}\right)}{P_{t}}
$$

Dimana r adalah biaya modal ekuitas. Bt adalah nilai buku per lembar saham, $\mathrm{Xt}+1$ adalah laba per saham diperiode berikutmya, dan $\mathrm{Pt}$ adalah harga saham pada periode tertentu.

\section{Manajemen Laba}

Variabel independen dalam penelitian ini adalah manajemen laba. Mengikuti penelitian oleh Jones (1991) dan Dechow et.al (1995), manajemen laba diukur dengan menggunakan proxy discretionary accruals, yaitu menghitung total akrual dengan menggunakan pendekatan aliran kas cash flow approach : 


\section{$\mathrm{TAC}=$ Net Income - Cash Flows from operations}

Dimana TAC adalah total akrual, net income adalah laba bersih tahun berjalan dan cash flow from operations adalah arus kas operasi. Selanjutnya untuk memperoleh akrual diskresioner, langkah awal yang harus dilakukan adalah menentukan koefisien dari regresi total akrual

$$
\text { TAit/Ait-1 = } \beta 1\left(1 / \text { Ait-1) }+\beta 2\left(\_ \text {Revt / Ait-1 }\right)+\beta 3(\text { PPEt / Ait-1 })+e\right.
$$

Dimana TAit adalah total akrual, Ait-1 adalah total aktiva pada periode sebelumnya, Revt adalah perubahan pendapatan pada periode tertentu dan PPEt adalah total aktiva tetap pada periode tertentu. Setelah mendapatkan angka regresi, maka angka tersebut digunakan untuk memprediksi akrual nondiskresioner melalui persamaan :

$$
\text { NDAit }=\beta 1\left(1 / A_{i t-1}\right)+\beta 2\left(\_ \text {Revt/Ait-1 }{ }_{-} \text {Rect } / A_{i t-1}\right)+\beta 3\left(\text { PPEt } / A_{i t-1}\right)
$$

Dimana NDAit adalah non diskresioner akrual dan Rect adalah perubahan piutang pada periode tertentu. Untuk menghitung nilai discretionary accruals (DACC) yang merupakan ukuran earnings management, setelah akrual non diskresioner, kemudian akrual diskresioner dapat dihitung dengan mengurangkan total akrual dengan akrual non diskresioner, diperoleh rumus :

$$
\mathrm{DA}_{i t}=\mathrm{TA}_{\mathrm{it}} / \mathrm{A}_{\mathrm{it}-1}-\mathrm{NDA} \text { it }
$$

\section{Siklus Hidup Perusahaan}

Variabel moderasi dalam penelitian ini adalah siklus hidup perusahaan. Mengikuti penelitian oleh Dickinson (2007) dan Hasan (2015), siklus hidup perusahaan diukur dengan menggunakan pengklasifikasian tahapan berdasarkan pola arus kas (cash flow patterns).

Tabel 2

Kriteria Pengklasifikasian Siklus Hidup Perusahaan (Dickinson, 2007)

\begin{tabular}{|l|l|l|l|l|}
\hline Jenis Arus Kas & Pengenalan & Pertumbuhan & Mature & Decline \\
\hline Operasi & (-) Arus Kas & (+) Arus Kas & (+)Arus Kas & (-) Arus Kas \\
\hline Investasi & (-) Arus Kas & (-) Arus Kas & (-)Arus Kas & (+) Arus Kas \\
\hline Pendanaan & (+) Arus Kas & (+) Arus Kas & (-)Arus Kas & (+/-) Arus Kas \\
\hline
\end{tabular}

(Sumber Dickinson, 2007)

Metode arus kas banyak digunakan karena dianggap lebih sesuai dalam mengklasifikasikan tahapan siklus hidup perusahaan sesuai kelompoknya. Selanjutnya setiap tahapan perusahaan dimasukkan kedalam skala interval. 
Tabel 3

Nomor Kode Untuk Tahapan Siklus Hidup Perusahaan

\begin{tabular}{|c|c|}
\hline No. Kode & Tahapan Siklus Hidup Perusahaan \\
\hline 1 & Start $-U p$ \\
\hline 2 & Growth \\
\hline 3 & Mature \\
\hline 4 & Decline \\
\hline
\end{tabular}

\section{Variabel Kontrol}

\section{Ukuran Perusahaan (FS)}

Untuk mengukur ukuran perusahaan, dapat digunakan rumus berikut ini:

$$
\text { FirmSize }=\text { Log TotalAset }
$$

\section{Leverage}

Untuk mengukur leverage, dapat digunakan rumus berikut ini:

$$
\text { Lev }=\frac{\text { Total utang }}{\text { Total aset }}
$$

\section{Model Penelitian}

\section{Uji Pengaruh Manajemen Laba dan Cost of Equity Capital}

Adapun untuk menguji pengaruh manajemen laba dan cost of equity capital menggunakan persamaan regresi sebagai berikut:

\section{Model 1:}

$\operatorname{CoEC}_{i t}=\alpha_{i}+\boldsymbol{\beta}_{i 1} \boldsymbol{E M}_{i t}+\beta_{i 2} F S_{i t}+\beta_{i 3} L E V_{i t}+e_{i t}$

Dimana, $\beta_{1} E M_{i t}$ menggambarkan besaran pengaruh manajemen laba terhadapcost of equity capital.

\section{Pengaruh Siklus Hidup Perusahaan dalam Memoderasi Hub.Manajemen Laba dan Cost of Equity Capital}

Adapun untuk menguji pengaruh siklus hidup perusahaan dalam memoderasi hubungan manajemen laba dan cost of equity capital menggunakan persamaan regresi sebagai berikut:

\section{Model 2:}

$\operatorname{CoEC}_{i t}=\alpha_{i}+\beta_{i 1} E M_{i t}+\beta_{i 2} L C Y_{i t}+\boldsymbol{\beta}_{i 3} \boldsymbol{E M}_{i t} \boldsymbol{x} \boldsymbol{L C} \boldsymbol{Y}_{i t}+\beta_{i 4} F S_{i t}+\beta_{i 5} L E V_{i t}+e_{i t}$

Dimana, $\beta_{i 3} E M_{i t} \times L C Y_{i t}$ menggambarkan besaran pengaruh siklus hidup perusahaan dalam memoderasi hubungan manajemen laba terhadap cost of equity capital.

\section{HASIL DAN PEMBAHASAN}

\section{Statistik Deskriptif}

Sebelum variabel penelitian dianalisis dengan melakukan pengujian rumus statistik eviews 10, data dari masing-masing variabel penelitian dideskripsikan terlebih dahulu. Hal ini dimaksudkan 
agar dapat memberikan gambaran tentang masing-masing variabel yang diteliti. Tabel 4 analisis Deskriptif akan menggambarkan statistik deskriptif dari 60 perusahaan manufaktur yang dijadikan sampel penelitian yang akan dianalisis lebih lanjut. Pada Tabel 4 analisis deskriptif,

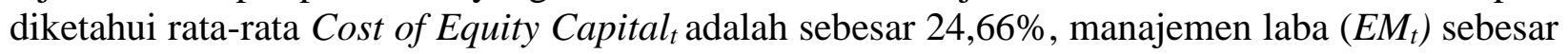
$5,54 \%$, siklus hidup perusahaan $\left(L C Y_{t}\right)$ sebesar $20,47 \%$, ukuran perusahaan (FS) sebesar 12,4373 dan leverage sebesar $46,02 \%$.

Tabel 4

Hasil Statistik Deskriptif

\begin{tabular}{|c|c|c|c|c|c|}
\hline \multicolumn{6}{|c|}{ Descriptive statistics } \\
\hline Variabel & Mean & Median & Maximum & Minimum & $\begin{array}{c}\text { Std. } \\
\text { Deviasi }\end{array}$ \\
\hline $\operatorname{CoEC}(\mathrm{t})$ & -0.2466 & -0.4693 & 4.4122 & -8.8700 & 1.1254 \\
\hline $\mathrm{EM}(\mathrm{t})$ & 0.0544 & 0.0381 & 0.4301 & 0.0002 & 0.0575 \\
\hline $\operatorname{LCY}(\mathrm{t})$ & 2.5533 & 3.0000 & 4.0000 & 1.0000 & 0.6991 \\
\hline EM.LCY (t) & 0.1354 & 0.0943 & 1.1005 & 0.0005 & 0.1542 \\
\hline $\operatorname{SIZE}(\mathrm{t})$ & 12.4373 & 12.3386 & 14.4708 & 10.9997 & 0.7304 \\
\hline $\operatorname{LEV}(\mathrm{t})$ & 0.4602 & 0.4173 & 1.5711 & 0.0838 & 0.2333 \\
\hline $\mathrm{n}=300$ & & & & & \\
\hline
\end{tabular}

(Sumber: Data Olahan Eviews10 tahun 2019)

\section{Analisis Model Regresi Panel}

Berdasarkan hasil Chow Test (Tabel 5) dan Hausman Test (Tabel 6) dengan menggunakan eviews10. Hasil Estimasi Model Regresi Panel, digunakan dalam model ini adalah Fixed Effect Model (FEM) untuk Model 1 dan Model 2. Serta, perlu dilakukan uji asumsi klasik terhadap kedua model tersebut (Hasil Uji Asumsi Klasik: Gambar 2, Gambar 3, Tabel 5, Tabel 6, Tabel 7, Tabel 8, Tabel 9, dan Tabel 10).

Tabel 5

Hasil Chow Test atau Likelyhood Test

\begin{tabular}{|lcccc|}
\hline \multicolumn{3}{|c|}{ Cross-section Chi-square } \\
\cline { 1 - 2 } Model Penelitian & Statistic & & d.f & Prob \\
\hline \hline Model 1 & 418.5223 & & 59 & 0,0000 \\
Model 2 & 415.7418 & & 59 & 0,0000 \\
\hline
\end{tabular}

(Sumber: Data Olahan Eviews10 tahun 2019)

Tabel 6

Hasil Hausman Test

\begin{tabular}{|lccc|}
\hline \multicolumn{4}{c|}{ Cross-section random } \\
\cline { 1 - 4 } Model Penelitian & $\begin{array}{c}\text { Chi-Sq. } \\
\text { Statistic }\end{array}$ & $\begin{array}{c}\text { Chi-Sq. } \\
\text { d.f }\end{array}$ & Prob \\
\cline { 3 - 4 } & $\begin{array}{l}\text { S2,0901 } \\
\text { Model 1 }\end{array}$ & 3 & 0,0000 \\
Model 2 & 35,6288 & 3 & 0,0000 \\
\hline
\end{tabular}

(Sumber: Data Olahan Eviews10 tahun 2019) 


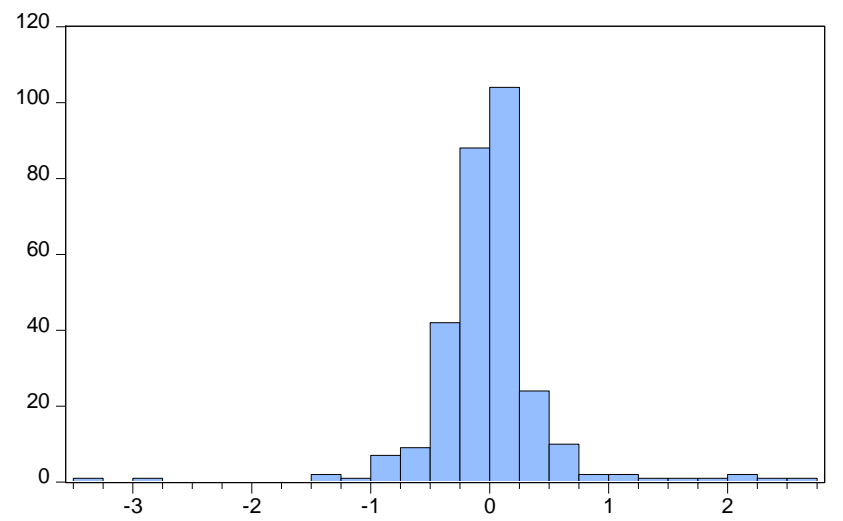

Series: Standardized Residuals Sample 20132017

Observations 300

Mean $\quad 1.07 e-17$

Median $\quad-0.002561$

Maximum 2.638398

Minimum $\quad-3.318200$

Std. Dev. $\quad 0.521632$

Skewness $\quad-0.069780$

Kurtosis $\quad 15.55556$

Jarque-Bera $\quad 1970.769$

Probability $\quad 0.000000$

(Sumber: Data Olahan Eviews10 tahun 2019)

Gambar 2

Hasil Uji Normalitas Residual Model 1

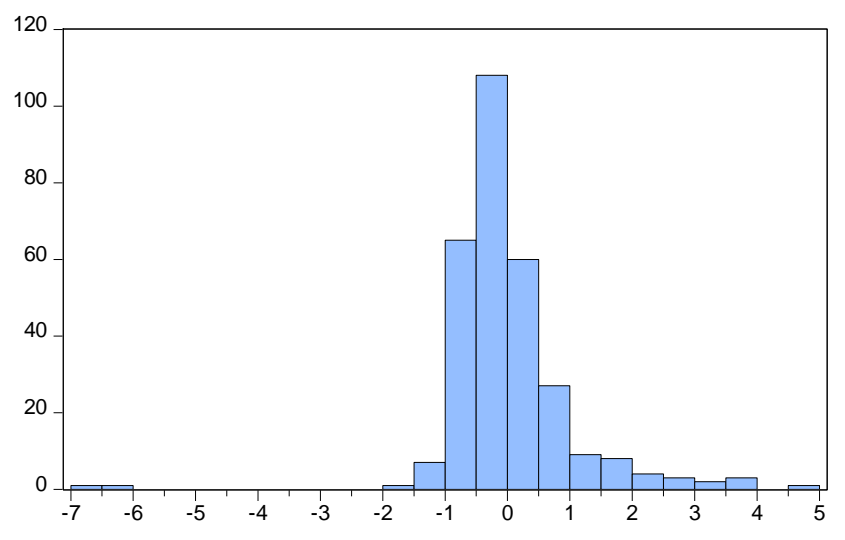

\begin{tabular}{|lc|}
\hline Series: Standardized Residuals \\
Sample 20132017 \\
Observations & 300 \\
& \\
Mean & $9.05 \mathrm{e}-16$ \\
Median & -0.192701 \\
Maximum & 4.849947 \\
Minimum & -6.938174 \\
Std. Dev. & 1.042965 \\
Skewness & -0.344927 \\
Kurtosis & 15.93306 \\
& \\
Jarque-Bera & 2096.751 \\
Probability & 0.000000
\end{tabular}

(Sumber: Data Olahan Eviews10 tahun 2019)

Gambar 3

Hasil Uji Normalitas Residual Model 2

Tabel 7

Hasil Uji Heterokedastisitas

Heterokedasticity Test : White

Model Penelitian

Obs*R-squared

Prob.

Chi-

Square

\begin{tabular}{|lrr|}
\hline Model 1 & 8.1028 & 0.1732 \\
Model 2 & 8.7379 & 0.2965 \\
\hline
\end{tabular}

(Sumber: Data Olahan Eviews10 tahun 2019) 
Tabel 8

Hasil Uji Multikolinearitas Model 1

\begin{tabular}{|l|rrr|}
\hline & EM $(\mathrm{t})$ & $\mathrm{SIZE}(\mathrm{t})$ & $\mathrm{LEV}(\mathrm{t})$ \\
\hline EM $(\mathrm{t})$ & 1.0000 & -0.1242 & 0.2753 \\
$\operatorname{SIZE}(\mathrm{t})$ & -0.1242 & 1.0000 & 0.0331 \\
$\operatorname{LEV}(\mathrm{t})$ & 0.2753 & 0.0331 & 1.0000 \\
\hline
\end{tabular}

(Sumber: Data Olahan Eviews10 tahun 2019)

Tabel 9

Hasil Uji Multikolinearitas Model 2

\begin{tabular}{|l|rrrrr|}
\hline & \multicolumn{1}{|c}{ EM $(\mathrm{t})$} & LCY $(\mathrm{t})$ & EM.LCY $(\mathrm{t})$ & \multicolumn{1}{c|}{ SIZE $(\mathrm{t})$} & \multicolumn{1}{c|}{ LEV $(\mathrm{t})$} \\
\hline EM $(\mathrm{t})$ & 1.0000 & -0.0895 & 0.0335 & -0.1242 & 0.2753 \\
LCY $(\mathrm{t})$ & -0.0895 & 1.0000 & 0.1803 & 0.0030 & -0.2906 \\
EM.LCY (t) & 0.9335 & 0.1803 & 1.0000 & -0.1185 & 0.1973 \\
SIZE (t) & -0.1242 & 0.0030 & -0.1185 & 1.0000 & 0.0331 \\
Lev $(\mathrm{t})$ & 0.2753 & -0.2906 & 0.1973 & 0.0331 & 1.0000 \\
\hline
\end{tabular}

(Sumber: Data Olahan Eviews10 tahun 2019)

Tabel 10

Hasil Uji Durbin Watson

\begin{tabular}{|lc|}
\hline \multicolumn{2}{|c|}{ Uji Durbin Watson } \\
\hline Model Penelitian & Durbin-Watson Stat \\
\hline \hline Model 1 & 2.0161 \\
Model 2 & 2.0182 \\
\hline
\end{tabular}

(Sumber: Data Olahan Eviews10 tahun 2019)

\section{Uji Model}

Berdasarkan Tabel 11, hasil regresi panel model 1 yaitu pengaruh manajemen laba terhadap cost of equity capital, diketahui nilaiadjusted $R^{2}$ yang diperoleh adalah sebesar $72,90 \%$. Artinya, sebagian besar variabel dependen telah diejalaskan oleh variabel independen pada model penelitian. Kemudian diketahui bahwa F-statistic Model 1 signifikan pada $\alpha$ 5\%, yaitu 0,0000< 0,05\%. Artinya, model 1 menunjukkan tingkatan yang baik (good overall model fit), sehingga layak digunakan untuk mengukur pengaruh manajemen laba terhadapcost of equity capital.Untuk t-statistik pada Model 1 diketahui bahwa koefisien regresi $\beta_{i 1} E M_{t}$ bernilai positif yaitu 0.0634 , $\mathrm{t}$ hitung 0.0907 (t-hitung < t-tabel, $0.0907<2.0025$ ) dan tidak signifkan pada $\alpha 5 \%$. Berdasarkan hasil regresi dari model 1 dapat disimpulkan bahwa hipotesis pertama"semakin tinggi praktik manajemen laba maka akan meningkatkan cost of equity capital" ditolak.

Berdasarkan Tabel 11, hasil regresi panel model 2 yaitu pengaruh siklus hidup perusahaan dalam memoderasi hubungan manajemen labadancost of equity capital, diketahui nilaiadjusted $R^{2}$ yang diperoleh adalah sebesar 72,67\%. Artinya, sebagian besar variabel dependen telah diejalaskan oleh variabel independen pada model penelitian. Kemudian diketahui bahwa F-statistic Model 2 signifikan pada $\alpha 5 \%$, yaitu yaitu 0.0000>0.05\%. Artinya, model 2 menunjukkan tingkatan yang baik(good overall model fit), sehingga layak digunakan untuk 
mengukur pengaruh, siklus hidup perusahaan dalam memoderasi hubungan manajemen labadancost of equity capital.Untuk t-statistik pada Model 2 diketahui bahwa koefisien regresi $\beta_{3} E M \quad x \quad L C Y$ bernilai negatif yaitu -0.1069 , t-hitung -0.1083 (t-hitung < t-tabel, $0.1083<2.0032$ ), dan tidak signifkan pada $\alpha 5 \%$. Berdasarkan hasil regresi dari model 2 dapat disimpulkan bahwa hipotesis pertama"semakin rendahmanajemen laba maka biaya modal ekuitas juga akan rendah, hubungan tersebut menguat atau melemah pada saat tahapan siklus perusahaan semakin tinggi” ditolak.

Tabel 11

Hasil Regresi Panel

\begin{tabular}{|c|c|c|c|c|}
\hline \multicolumn{5}{|c|}{ Persamaan Regresi Model 1} \\
\hline \multicolumn{5}{|c|}{ Persamaan Regresi Model 2} \\
\hline $\mathrm{CoECs}$ & \multicolumn{4}{|c|}{$\begin{array}{l}\alpha \mathrm{i}+\boldsymbol{\beta} \mathbf{i}_{1} \mathbf{E M i t}+\beta \mathrm{i}_{2} \mathrm{LC} \\
\beta \mathrm{i}_{5} \mathrm{LEVit}+\text { eit }\end{array}$} \\
\hline \multicolumn{2}{|l|}{ Variabel } & Prediksi & Model 1 & Model 2 \\
\hline \multirow[t]{2}{*}{ Konstanta } & Coef. & & -15.2182 & -15.2694 \\
\hline & t-stat & & -3.6398 & -3.6226 \\
\hline \multirow[t]{2}{*}{$\mathrm{EM}(\mathrm{t})$} & Coef. & + & 0.0634 & 0.3421 \\
\hline & t-stat & & 0.0907 & 0.1295 \\
\hline \multirow[t]{2}{*}{$\operatorname{LCY}(\mathrm{t})$} & Coef. & & & 0.0127 \\
\hline & t-stat & & & 0.1417 \\
\hline \multirow[t]{2}{*}{ EM.LCY } & Coef. & & & -0.1069 \\
\hline & t-stat & & & -0.1083 \\
\hline \multirow[t]{2}{*}{$\operatorname{SIZE}(\mathrm{t})$} & Coef. & & 1.2986 & 1.2999 \\
\hline & t-stat & & 3.8880 & 3.8723 \\
\hline \multirow[t]{2}{*}{$\operatorname{LEV}(\mathrm{t})$} & Coef. & & -2.5698 & -2.5656 \\
\hline & t-stat & & -7.2550 & -7.1682 \\
\hline \multicolumn{3}{|l|}{ Adj R-Square } & 0.7290 & 0.7267 \\
\hline \multicolumn{3}{|l|}{ F-Statistic } & $13.9708 * * *$ & $13.4215^{* * *}$ \\
\hline \multicolumn{5}{|c|}{ Keterangan } \\
\hline \multicolumn{5}{|c|}{ EM (t) : Manajemen laba tahun berjalan } \\
\hline \multicolumn{5}{|c|}{ LCY $(\mathrm{t}):$ Siklus Hidup Perusahaan } \\
\hline \multicolumn{5}{|c|}{ SIZE (t) : Ukuran perusahaan tahun berjalan } \\
\hline \multicolumn{5}{|c|}{ LEV $(\mathrm{t}) \quad$ : Leverage tahun berjalan } \\
\hline \multicolumn{5}{|c|}{$\mathrm{n} \quad: 300$} \\
\hline \multicolumn{5}{|c|}{$* * *, * *, *$ : Signifikan pada $\alpha 1 \%, 5 \%$, dan $10 \%$} \\
\hline
\end{tabular}

(Sumber: Data Olahan Eviews10 tahun 2019) 
Tabel 12

Hasil Regresi per Tahapan Siklus Hidup Perusahaan

\begin{tabular}{|c|c|c|c|c|c|}
\hline \multicolumn{6}{|c|}{ Persamaan Regresi Tahapan Start-Up } \\
\hline \multicolumn{6}{|c|}{ Persamaan Regresi Tahapan Growth } \\
\hline \multirow{2}{*}{\multicolumn{6}{|c|}{ 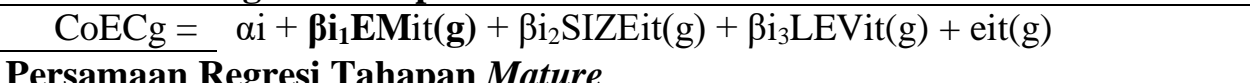 }} \\
\hline Persamaan Regresi Tahapan Mature & & & & & \\
\hline \multirow{2}{*}{\multicolumn{6}{|c|}{$\begin{array}{l}\text { CoECm }=\alpha i+\beta \mathbf{i}_{1} \text { EMit }(\mathbf{m})+\beta \mathrm{i}_{2} \operatorname{SIZEit}(\mathrm{m})+\beta \mathrm{i}_{3} \mathrm{LEVit}(\mathrm{m})+\operatorname{eit}(\mathrm{m}) \\
\text { Persamaan Regresi Decline }\end{array}$}} \\
\hline \multirow{2}{*}{\multicolumn{6}{|c|}{$\begin{array}{l}\text { Persamaan Regresi Decline } \\
\qquad \mathrm{CoECd}=\alpha \mathrm{i}+\boldsymbol{\beta} \mathbf{i}_{1} \text { EMit }(\mathbf{d})+\beta \mathrm{i}_{2} \operatorname{SIZEit}(\mathrm{d})+\beta \mathrm{i}_{3} \operatorname{LEVit}(\mathrm{d})+\operatorname{eit}(\mathrm{d})\end{array}$}} \\
\hline & & & & & \\
\hline \multicolumn{2}{|l|}{ Variabel } & Start-Up & Growth & Mature & Decline \\
\hline \multirow[t]{2}{*}{ Konstanta } & Coef. & 3.1864 & 3.1644 & 3.4441 & 21.3699 \\
\hline & t-stat & 0.8264 & 2.2167 & 4.7932 & 2.6333 \\
\hline \multirow[t]{2}{*}{$\mathrm{EM}(\mathrm{t})$} & Coef. & -4.7183 & -2.8864 & -2.4432 & -9.6933 \\
\hline & t-stat & -1.3479 & -1.9804 & -2.9667 & -2.4216 \\
\hline \multirow[t]{2}{*}{$\operatorname{SIZE}(\mathrm{t})$} & Coef. & -0.1227 & -0.2397 & -0.2848 & -1.6637 \\
\hline & t-stat & -0.3707 & -2.0941 & -4.9532 & -2.5571 \\
\hline \multirow[t]{2}{*}{ LEV (t) } & Coef. & -2.2745 & -0.4344 & -0.1927 & -3.2063 \\
\hline & t-stat & -2.5946 & -1.0016 & -0.7781 & -4.5058 \\
\hline \multicolumn{2}{|c|}{ Adj R-Square } & 0.2637 & 0.0862 & 0.1571 & 0.8665 \\
\hline \multicolumn{2}{|c|}{ F-Statistic } & $3.8649^{* *}$ & $3.4533 * *$ & $11.3782^{* * * *}$ & $13.9763 * *$ \\
\hline \\
\hline \multicolumn{6}{|c|}{ EM $(t):$ Manajemen laba tahun berjalan } \\
\hline \multicolumn{6}{|c|}{ SIZE (t) : Ukuran perusahaan tahun berjalan } \\
\hline \multicolumn{6}{|c|}{ LEV $(t) \quad$ : Leverage tahun berjalan } \\
\hline \multicolumn{6}{|c|}{$\mathrm{n}: 300$} \\
\hline$* * *, * *, *: \mathrm{S}$ & ifika & $1 \%, 5$ & & & \\
\hline
\end{tabular}

(Sumber: Data Olahan Eviews10 tahun 2019)

\section{Pembahasan}

\section{Pengaruh Manajemen Laba terhadap Cost of Equity Capital}

Hipotesis pertama pada penelitian ini adalah manajemen laba berpengaruh positif terhadap cost of equity capital, dimana semakin tinggi manajemen laba maka akan meningkatkan cost of equity capital. Variabel cost of equity capital pada penelitian ini diukur dengan menggunakan model Ohlson (1995) yang dimodifikasi oleh Utami (2005). Variabel manajemen laba pada penelitian ini diukur dengan menggunakan proxy discretionary accrual.

Berdasarkan hasil penelitian pada perusahaan sektor manufaktur yang terdaftar di BEI pada tahun 2013-2017, ditemukan bahwa hipotesis $\left(\mathrm{H}_{1}\right)$ ditolak. Hal ini menunjukkan bahwa manajemen laba berpengaruh positif namun tidak signifikan terhadap cost of equity capital. Hal ini dapat dilihat dari hasil regresi panel pada tabel 11, yang menunjukkan bahwa nilai koefisien manajemen laba sebesar 0.063 menunjukkan bahwa apabila manajemen laba meningkat satu poin, maka cost of equity capital meningkat sebesar 0.063 poin. Tingkat signifikan dari variabel $\beta_{1}$ EMt lebih besar dari $\alpha 5 \%$, yaitu $0,928>5 \%$ serta, nilai t-hitung < t-tabel yaitu, 
$0.0907<2.0025$. Hal ini menunjukkan bahwa manajemen laba tidak berpengaruh signifikan terhadap cost of equity capital.

Pengaruh yang positif namun tidak signifikan mengindikasikan bahwa besar kecilnya manajemen laba belum tentu menjadi pengaruh meningkatnya cost of equity capital. Hal tersebut menunjukkan bahwa manajemen laba belum dapat menjelaskan pengaruhnya secara signifikan terhadap cost of equity capital. Hasil penelitian ini menjelaskan bahwa cost of equity capital tidak akan meningkat seiring dengan meningkatnya manajemen laba. Manajemen laba merupakan tindakan manajemen dalam memanipulasi akun-akun dan informasi yang terdapat dalam laporan keuangan guna untuk memenuhi kepentingannya sendiri, seperti menaikkan laba, menurunkan laba atau perataan laba. Manajemen laba dilakukan untuk menutupi kekurangankekurangan yang terdapat dalam laporan keuangan sehingga laporan keuangan disajikan dengan baik, sehingga dapat menarik investor untuk berinvestasi pada perusahaan.

Hasil penelitian ini konsisten dengan penelitian Ifonie (2012), Purwanto (2013), Andriani (2013), dan Murwaningsari (2012). Peneliti-peneliti sebelumnya menyatakan bahwa manajemen laba tidak berpengaruh signifikan terhadap cost of equity capital. Menurut Ifonie (2012) investor telah mengantisipasi adanya manajemen laba yang dilakukan oleh perusahaan, sehingga investor tidak hanya melihat hasil laporan keuangan tetapi melihat faktor lain dalam mengambil keputusan untuk menanamkan modal dalam perusahaan tersebut. Dalam mengambil keputusan untuk berinvestasi pada perusahaan, investor juga akan mempertimbangkan ukuran dari perusahaan, risiko pasar dan juga opini atas audit laporan keuangan perusahaan tersebut.

Hasil penelitian ini bertentangan dengan penelitian oleh Utami (2005), Vidiyanto (2009), dan Cecilia dan Sigit Utomo (2012), yang menyatakan bahwa manajemen laba berpengaruh signifikan terhadap cost of equity capital. Manajemen laba akan meningkatkan risiko perusahaan jika tindakan tersebut dilakukan bertujuan untuk menutupi kinerja perusahaan yang tidak baik. Francis et al. (2004, 2005) dan Utami (2005) menunjukkan bahwa manajemen laba mempunyai pengaruh positif terhadap biaya modal ekuitas. Semakin besar praktik manajemen laba yang dilakukan oleh perusahaan maka semakin besar biaya yang harus dikeluarkan oleh perusahaan. Manajemen laba dilakukan semata-mata untuk mempengaruhi persepsi investor atas risiko perusahaan (Stowoly dan Breton, 2000).

Berdasarkan hasil penelitian, dapat disimpulkan bahwa besar kecilnya praktik manajemen laba yang dilakukan oleh manajemen belum mampu mempengaruhi meningkatnya cost of equity capital artinya, besarnya cost of equity capital tidak dipengaruhi oleh semakin besarnya manajemen laba yang dilakukan.

\section{Pengaruh Siklus Hidup Perusahaan dalam Memoderasi Hubungan Manajemen Laba dan Cost of Equity Capital}

Hipotesis kedua pada penelitian ini adalah semakin rendah manajemen laba maka akan menurunkan cost of equity capital, hubungan tersebut semakin menguat pada saat tahapan siklus hidup semakintinggi. Variabel siklus hidup perusahaan pada penelitian ini diukur menggunakan model Dickinson (2011) yang menentukan tahapan siklus hidup perusahaan dengan menggunakan laporan arus kas.

Berdasarkan hasil uji hipotesis kedua, ditemukan dalam penelitian ini bahwa hipotesis $\mathrm{H}_{2}$ ditolak. Hasil penelitian ini tidak dapat membuktikan bahwa siklus hidup perusahaan dapat memperkuat atau memperlemah hubungan manajemen laba dan cost of equity capital. Hal ini dapat dilihat dari hasil regresi panel pada tabel 11, yang menunjukkan bahwa nilai signifikasi variabel $\beta_{3}$ EMxLCYt yangtidak signifikan pada $\alpha 5 \%$, yaitu $0,9139<5 \%$ serta, hasil t-hitung < t- 
tabel yaitu, $-0.1083<2.0032$. Hasil ini menunjukkan bahwa siklus hidup perusahaan tidak mampu memperkuat atau memperlemah hubungan manajemen laba dengan cost of equity capital sehingga tinggi rendahnya siklus hidup perusahaan jugatidak mampu memperkuat atau memperlemah hubungan manajemen laba dengan cost of equity capital.

Hasan et al (2015) menyatakan bahwa siklus hidup memiliki pengaruh yang signifikan pada kemampuan perusahaan untuk menarik investor, yang akhirnya mempengaruhi biaya modal ekuitas perusahaan.Siklus hidup perusahaan merupakan perkembangan perusahaan yang ditandai dengan adanya tahapan-tahapan yang dilalui oleh setiap perusahaan. Perusahaan yang berada pada setiap siklus hidup perusahaan memiliki aliran kas, struktur pengendalian internal,dan sumber daya profesional yang berbeda.

Hasil penelitian ini bertentangan dengan penelitian oleh Shank dan Govindarajan (1992) yang menyatakan bahwa perusahaan pada tahap start-up dan growth menerapkan sistem pengendalian yang tidak ketat, dan pada tahap mature dan decline perusahaan menerapkan sistem pengendalian yang ketat, sehingga manajemen laba sering dilakukan pada tahap start-up dan growth daripada tahap mature dan decline. Penelitian oleh Shank dan Govindarajan(1992) menyimpulkan bahwa tahapan siklus hidup perusahaan yang semakin meningkat akan menyebabkan perusahaan melakukan praktik manajemen laba guna untuk mempertahankan perusahaannya.

Namun hasil penelitian ini menunjukkan bahwa perusahaan yang berada pada tahap startup dan decline, melakukan praktik manajemen laba yang lebih tinggi dibandingkan dengan perusahaan yang berada pada tahap growth dan mature. Kondisi tersebut menunjukkan bahwa perusahaan yang berada pada tahap start-up dan decline, melakukan praktik manajemen laba yang lebih tinggi pada pelaporan keuangan sehingga cost of equity capital juga tinggi, sedangkan perusahaan yang berada pada tahap growth dan mature, manajemen melakukan praktik manajemen laba yang rendah sehingga cost of equity capital juga rendah. Hasil tersebut sejalan dengan penelitian oleh Hasan et al. (2015) yang menyatakan bahwa biaya ekuitas lebih tinggi pada tahap start-up dan decline dan lebih rendah pada tahap growth dan mature, sehingga manyerupai pola berbentuk-U.

Dapat dilihat pada dari hasil regresi untuk setiap tahapan siklus hidup perusahaan pada Tabel 12 yang menunjukkan pada tahap start-up, nilai signifikansi variabel manajemen laba tidak signifikan pada $\alpha 5 \%$, yaitu $0,1921<5 \%$ serta, hasil t-hitung < t-tabel yaitu, $-1.3479<$ 2.0555. Hasil ini menunjukkan bahwa pada tahap start-up, manajemen laba tidak berpengaruh signifikan terhadap cost of equity capital. Pada tahap growth, nilai signifikansi variabel manajemen laba signifikan pada $\alpha 5 \%$, yaitu $0,0513<5 \%$ serta, hasil t-hitung < t-tabel yaitu, $1.9804<1.9917$. Hasil ini menunjukkan bahwa pada tahap growth, manajemen laba berpengaruh signifikan terhadap cost of equity capital. Pada tahap mature, nilai signifikansi variabel manajemen laba signifikan pada $\alpha 5 \%$, yaitu $0,0035<5 \%$ serta, hasil t-hitung < t-tabel yaitu, $2.9666<1.9745$. Hasil ini menunjukkan bahwa pada tahap mature, manajemen laba berpengaruh signifikan terhadap cost of equity capital. Pada tahap decline, nilai signifikansi variabel manajemen laba tidak signifikan pada $\alpha 5 \%$, yaitu $0,0940<5 \%$ serta, hasil t-hitung < t-tabel yaitu, $-2.4216<2.7765$. Hasil ini menunjukkan bahwa pada tahap decline, manajemen laba tidak berpengaruh signifikan terhadap cost ofequity capital.

Hasil tersebut menyimpulkan bahwa pada tahap growth dan mature manajemen laba yang dilakukan oleh perusahaan berpengaruh terhadap biaya modal ekuitas perusahaan, sedangkan pada tahap start-up dan decline manajemen laba tidak berpengaruh terhadap biaya modal ekuitas. Hal tersebut dikarenakan pada tahap start-up dan decline, investor tidak melihat risiko 
yang terdapat pada perusahaan dan risiko atas investasi yang dilakukan oleh investor itu sendiri, namun investor lebih tertarik untuk melihat informasi-informasi yang terdapat pada pelaporan keuangan perusahaan yang berada pada tahap growth dan mature. Hasan et al (2015) menyatakan bahwa siklus hidup perusahaan memiliki implikasi penting untuk menarik investor, yang pada akhirnya meningkatkan likuiditas saham dan mempengaruhi biaya modal ekuitas (cost of equity capital).

Beberapa faktor yang menyebabkan hipotesis ini ditolak adalah karena terdapatnya ketimpangan sampel pada setiap tahapan siklus hidup perusahaan. Setiap perusahaan manufaktur tidak berada pada tahapan siklus yang sama setiap tahunnya, dan perusahaan manufaktur yang dijadikan sampel pada penelitian ini merupakan perusahaan yang terdaftar di BEI dan sudah go public sehingga banyak perusahaan yang berada pada tahapan yang matang dibandingkan dengan tahap pengenalan dan penurunan. Kondisi tersebut menyebabkan terjadinya ketimpangan sampelsehingga hipotesis yang kedua ini ditolak. Berdasarkan penelitian ini, siklus hidup perusahaan merupakan variabel yang tidak berpengaruh terhadap manajemen laba dan cost of equity capital.

\section{SIMPULAN, KETERBATASAN, DAN SARAN \\ Simpulan}

Berdasarkan hasil temuan penelitian pada perusahaan manufaktur pada tahun 2013-2017 dan pengujian hipotesis yang diajukan sebelumnya dapat disimpulkan bahwa Hipotesis pertama ditolak, dimana manajemen laba berpengaruh positif dan tidak signifikan terhadap cost of equity capital, yang artinya besar kecilnya perilaku manajemen laba tidak dapat menentukan peningkatan biaya modal ekuitasnya. Manajemen laba di ukur menggunakan proxy discresionary accrual, sedangkan cost of equity capital diukur menggunakan pengukuran model Ohlson (1995) yang telah dimodifikasi oleh Utami (2005).

Sedangkan hipotesis kedua ditolak, dimana siklus hidup perusahaan tidak mampu memperkuat atau memperlemah hubungan manajemen laba terhadap cost of equity capital, yang artinya siklus hidup perusahaan merupakan variabel moderating yang tidak cocok digunakan dalam penelitian ini. Siklus hidup perusahaan diukur dengan menggunakan elemen arus kas perusahaan.

\section{Keterbatasan}

Keterbatasan dari penelitian ini yang pertama adalah tidak semua sampel menyajikan data dalam laporan arus kas dengan lengkap, padahal data tersebut dibutuhkan untuk menentukan tahapantahapan yang dilalui oleh perusahaan di setiap tahunnya.Kedua, penelitian ini baru menggambarkan potret pada perusahaan manufaktur, sehingga data penelitian tidak dapat mewakili keseluruhan perusahaan pada BEI.

\section{Saran}

Bagi peneliti selanjutnya diharapkan dapat 1) menggunakan jenis perusahaan yang berbeda-beda dan memakai ruang lingkup sampel yang lebih luas. 2) menambah periode waktu yang lebih lama lagi agar hasil yang diperoleh lebih berkualitas. 3) menggunakan sampel yang menyajikan semua elemen data yang dibutuhkan untuk mengukur variabel siklus hidup perusahaan. 4) sebaiknya mempertimbangkan dan mencari variabel independen lainnya yang berhubungan dengan cost of equity capital. 


\section{DAFTAR PUSTAKA}

Anthony, R., \& Govindarajan, V. 2007. Management Control Systems. Edisi 12. Boston

Caecilia Antari Pratista dan Drs.YB Sigit Hutomo, M.BAcc.Akt. 2012. "Pengaruh Manajemen Laba Terhadap Biaya Modal Ekuitas Melalui Pengungkapan Corporate Social And Environmental Responsibility Sebagai Variabel Intervening”. Jurnal Riset Akuntansi Indonesia.

Câmara, A., San-Lin, C., Yaw-Huei, W. 2009. "Option implied cost of equity and its properties". Journal Futures Markets. Vol 29 (7) : 599-629.

Dechow, Patricia M., Richard G. Sloan, Any P. Sweeney., 1995, "Detecting Earnings Management". The Accounting Review 2. Vol 70 (2) : 193-225.

Dickinson, V. 2007. "Cash flow patterns as a proxy for firm life cycle". Accounting Review. Vol 86 (6) : 1964-1994.

Fama, E. F., and K. R. French. 2001. "Disappearing dividends: changing firm characteristics or lower propensity to pay?”.Journal of Financial Economic. Vol 60 (1) : 3-43.

Francis, J., R. Lafond, P. Olsson, dan K. Schipper. 2005. "The Market Pricing of Accruals Quality". Journal of Accountingand Economics. Vol 39 : 295-327.

Hasan, M. M., M. Hossain, A. Cheung and A. Habib. 2015. "Corporate life cycle and cost of equity capital”. Journal of Contemporary Accounting \& Economics. Vol 11(1) : 46-60.

Hastuti, S. 2006. "Perbedaan Perilaku Earnings Manajement Berdasarkan pada Life Cycle Perusahaan”. Tesis. Tidak Diterbitkan. Universitas Gadjah Mada : Yogyakarta

Healy, P.M., and J.M. Wahlen. 1999. A Review of The Earnings Management Literature and Its Implications for Standard Setting". Accounting Horizons. Vol13 (4) : 365-383.

Healy, P.M., and J.M. Wahlen. 1999. A Review of The Earnings Management Literature and Its Implications for Standard Setting". Accounting Horizons. Vol13 (4) : 365-383.

Hughes, J. S., Liu, J. And Liu, J. 2007. "Information asymmetry, diversification, and cost of capital".The Accounting Review. Vol 82 (3) : 705-729.

Husnan, S. dan Enny Pujiastuti. 1994.Dasar-dasar Manajemen Keuangan. Edisi Pertama. Yogyakarta : UPP AMP YKPN

Ifonie, Regina Reizky. 2012. "Pengaruh Asimetri Informasi Dan Manajemen Laba Terhadap Cost Of Equity”. Jurnal Ilmiah Mahasiswa Akuntansi. Vol 1(1).

Imran, Ali. 2012. "Pengaruh Ukuran Perusahaan, Pengungkapan Sukarela, dan Manajemen Laba terhadap Cost of Equity Capital".

Jensen, Meckling. 1976. "Theory of the Firm: Managerial Behavior, Agency Costs and Ownership Structure". Journal of Financial Economics. Vol 3 (4) : 305-360.

Jones, S. dan Sharma, R. 2001. "The association between the investment opportunity set and corporate financing and dividend decisions: some Australis Evidence". Managerial Finance.Vol 27 (3): 48-64.

Komalasari, Puput Tri, dan Baridwan, Zaki. 2001. Asimetri Informasi dan Cost of Equity Capital. Jurnal Riset Akuntansi Indonesia. Vol 4 (1) : 6481

Kurnia, Lisa dan M Yaser Arrafat. 2015. Pengaruh Manajemen laba dan Ukuran perusahaan terhadap biaya modal ekuitas pada perusahaan Manufaktur yang terdaftar di BEI. Jurnal Ilmiah Wahana Akuntasi. Vol 10 (1).

Lambert, R., Leuz, C., Verrecchia, R. 2007." Accounting information, disclosure, and the cost of capital". Journal of Accounting Research. Vol 45 : 385-420.

Ohlson, J. A. 1995. "Earnings, book values, and dividends in equity valuation". Journal of Accounting. Vol 11 (2) : 661-687. 
Purwanto, Agus .2013. "Pengaruh Manajemen Laba, Asymetri Information dan PengungkapanSukarela Terhadap Biaya Modal'.Simposium Nasional Akuntansi XV. Banjarmasin.

Stolowy, H., and G. Breton. 2000. "A Framework for The Clasification of Account Manipulations". Working Paper. http: // papers.ssrn.com.

Sulistyanto, H. S. 2008. Manajemen Laba Teori dan Model Empiris. Jakarta: PT Grasindo.

Utami, Wiwik. 2005. "Pengaruh Manajemen Laba terhadap Biaya Modal Ekuitas (Studi Perusahaan Manufaktur". Simposium Nasional Akuntansi VIII.

Verrecchia, R. 1982. "The Use of Mathematical Models in Financial Accounting". Journal of Accounting Research. 1-42. 